\title{
Transformation of Gulf Sivash (the Sea of Azov) in Conditions of Growing Salinity: \\ Changes of Meiobenthos \\ and Other Ecosystem Components (2013-2015)
}

\author{
Nickolai V. Shadrin ${ }^{\mathrm{a}, *}$, \\ Nelli G. Sergeeva ${ }^{\mathrm{a}}$, Aleksandr A. Latushkin ${ }^{\mathrm{b}}$, \\ Elena A. Kolesnikova a , Laura M. Kipriyanova', \\ Elena V. Anufriieva ${ }^{a}$ and Anna A. Chepyzhenko ${ }^{b}$ \\ ${ }^{a} A$.O. Kovalevsky Institute of Marine Biological Research RAS \\ 2 Nakhimov, Sevastopol, 299011, Russia \\ ${ }^{b}$ Marine Hydrophysical Institute RAS \\ 2 Kapitanskaya Str., Sevastopol, 299011, Russia \\ 'Institute for Water and Environmental Problems SB RAS \\ 2 Morskoy, Novosibirsk, 630090, Russia
} Received 13.05.2016, received in revised form 21.07.2016, accepted 04.11.2016

In April 2014, Ukraine has stopped the supply of Dnieper river water in the North Crimean Canal, bringing began to a salinity increase in the Gulf of Sivash (the Sea of Azov). Expeditions, which were conducted on Sivash in 2013-2015, have made it possible to evaluate the occurred changes in salinity, the concentration of total suspended solids (TSS), dissolved organic matter, as well as in macro- and meiobenthos, and plankton. Particular attention was paid Harpacticoida taxocene. In the 2014-2015, salinity was 40-70 g/L, it is significantly higher than in previous years (average $22 \mathrm{~g} / \mathrm{L}$ ). In 2014-2015, the concentration of TSS was three times higher than in 2013. Significant changes have occurred in benthos and plankton. Floating mats of green filamentous algae have developed intensively along coast, which noted the high number of meiobenthic Harpacticoida. In 2014-2015, species composition of Harpacticoida taxocene in the Sivash was differed from that in 2013; all of the marked species (8) were observed only in the plankton, there were only 2 species in mats, and 3 - on soft bottom. The authors conclude that the Sivash ecosystem moves into a new state.

Keywords: long-term changes, lagoons, salinity, benthos, the Sea of Azov.

DOI: 10.17516/1997-1389-2016-9-4-452-466.

(c) Siberian Federal University. All rights reserved

* Corresponding author E-mail address: snickolai@yandex.ru 


\title{
Трансформация залива Сиваш (Азовское море)
}

в условиях роста солености:

изменения мейобентоса

\section{и других компонент экосистемы (2013-2015 гг.)}

\author{
Н.В. Шадрин ${ }^{a}$, Н.Г. Сергеева ${ }^{a}$, \\ А.А. Латушкин ${ }^{\sigma}$, Е.А. Колесникова ${ }^{a}$, \\ Л.М. Киприяновав ${ }^{\text {, E.В. Ануфриева }{ }^{\text {a }} \text {, А.А. Чепыженко }}{ }^{\sigma}$ \\ ${ }^{a}$ Институт морских биологических исследований \\ имени А.О. Ковалевского РАН \\ Россия, 299011, Севастополь, пр. Нахимова, 2 \\ ${ }^{6}$ Морской гидрофизический институт РАН \\ Россия, 299011, Севастополь, ул. Капитанская, 2 \\ ${ }^{8}$ Институт водных и экологических проблем СО РАН, \\ Новосибирский филиал \\ Россия, 630090, Новосибирск, Морской проспект, 2
}

В апреле 2014 г. Украина прекратила подачу днепровской воды в Северо-Крымский канал, в результате чего в заливе Сиваш (Азовское море) начался рост солености. Экспедиции, проведенные на Сиваше в 2013-2015 г2., дали возможность оценить происшедчие изменения солености, концентрации общего взвешенного вещества (OBB), растворенного органического вещества (РОВ), макро- и мейобентоса, зоопланктона. Соленость в 2014-2015 г2. колебалась от 40 до 70 г/л, что значительно больше, чем в предыдущие годы (в среднем 22 г/л). Концентрация ОВВ в 2014-2015 г2. была в три раза выше, чем в 2013 г. Произошли существенные изменения в бентосе и планктоне. У берегов залива массово развились плавучие маты зеленых нитчатых водорослей, где отмечена высокая численность Harpacticoida. Видовой состав таксоиена Harpacticoida в заливе существенно отличался от такового в 2013 г., при этом все 8 найденныхх видов отмечены только в планктоне, в матах лишь 2 вида, а на мягких грунтах - 4. Делается вывод, что экосистема Сивата переходит в новое состояние.

Ключевые слова: долговременные изменения, лагуны, соленость, бентос, Азовское море.

\section{Введение}

В настоящее время происходят трансформации разных водных экосистем, вызванные изменениями глобальной климатической системы и антропогенной деятельностью (Ezhova et al., 2005; Conley et al., 2007; Аладин, Плотников, 2008; Shadrin, Anufriieva, 2013; El-Shabrawy et al., 2015). Индикация этих из- менений, понимание взаимосвязи причин и следствий - актуальные задачи современных экологических исследований водоемов. Мейобентос является важным функциональным компонентом водных экосистем, его доля в суммарной продукции донных животных в среднем составляет около 60 \% (Мокиевский, 2009). Вклад мейобентоса в видовое разно- 
образие, биомассу и продукцию донного сообщества увеличивается по мере нарастания экстремальности условий существования (Levin et al., 2009; Sergeeva, Zaika, 2013). Как правило, в таких биотопах мейобентос играет основную роль в передаче энергии и вещества от первичных продуцентов и детрита к более высоким трофическим уровням, включая рыб и водных птиц (Мокиевский, 2009). Несомненно, что изменения в структуре мейобентоса будут отражаться на функционировании других компонентов водных экосистем, в связи с этим мейобентос может быть одним из наиболее эффективных биоиндикаторов состояния водной среды (Semprucci et al., 2015; Zeppilli et al., 2015), поэтому в данной работе ему уделяется основное внимание.

Принятые политические решения могут не только влиять на социально-экономические процессы, но и вызывать существенные изменения экосистем. Примером этому может служить крупнейший залив Азовского моря

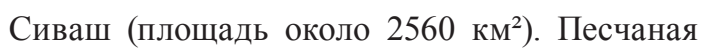
Арабатская стрелка отделяет его от моря, а через пролив Тонкий он имеет на севере свободный водообмен с Азовским морем (Воробьев, 1940). В первую половину ХХ в. Сиваш являлся полузамкнутой мелководной высокопродуктивной гипергалинной лагуной (средняя соленость 140 г/л, в южной части - до >200 г/л) (Воробьев, 1940; Зенкевич, 1963). Строительство Северо-Крымского канала (1963-1975 гг.) все изменило. С 1963 г. днепровская вода стала поступать в канал, ее использовали для орошения, а дренажные воды с орошаемых полей стали сбрасывать в Сиваш. Например, в 1985 г. 521 млн м³ воды сброшено в залив с территории Крыма и 109 млн м ${ }^{3}$ - со стороны Херсонской области, в результате этого соленость в заливе уменьшилась до 22,6 г/л в 1989 г. и до 17 г/л в 1997 г. (Гринченко, 2004). Это привело к формированию в заливе новой солоновато-водной экосистемы (Гетманенко и др., 1996; Гринченко, 2004; Загородняя, 2006; Киреева, Потеха, 2013). В апреле 2014 г. Украиной было принято политическое решение о прекращении подачи днепровской воды в Северо-Крымский канал, и к октябрю того же года в основной ветке канала воды уже не было (рис. 1). Сброс пресной воды в залив практически прекратился. В нем выросла соленость, и началась новая трансформация экосистемы Сиваша. Цель данной работы - на основе новых данных по мейобентосу и другим компонентам экосистемы залива Сиваш оценить современное состояние и происшедшие изменения в результате резкого увеличения солености.

\section{Материалы и методы}

Материалы для исследования были получены в шести экспедициях: в июне 2013 г. (до начала резкого осолонения), в июне 2014 г., в начале и конце октября 2014 г., в августе и октябре 2015 г. (рис. 2). Также с 2004 г. авторы проводили нерегулярные наблюдения за соленостью и состоянием биоты (рис. 2), полученные данные были учтены при анализе. Соленость, концентрацию общего взвешенного вещества (OBB) и растворенного органического вещества (РОВ) определяли при помощи биофизического зондирующего комплекса «Кондор», который использовали в «точечном» режиме (Сергеева и др., 2014). Его датчики помещали в сосуд с отобранными пробами воды. Для определения солености (стандартным методом через электропроводность) пробы воды, соленость которой была существенно выше океанической, разбавляли вдвое. В других случаях соленость измеряли ручным рефрактометром Kellong WZ212, температуру - электронным термометром РНН-830. В июне 2013 г. и августе 2015 г. пробы бентоса отбирали на участках с глубиной 


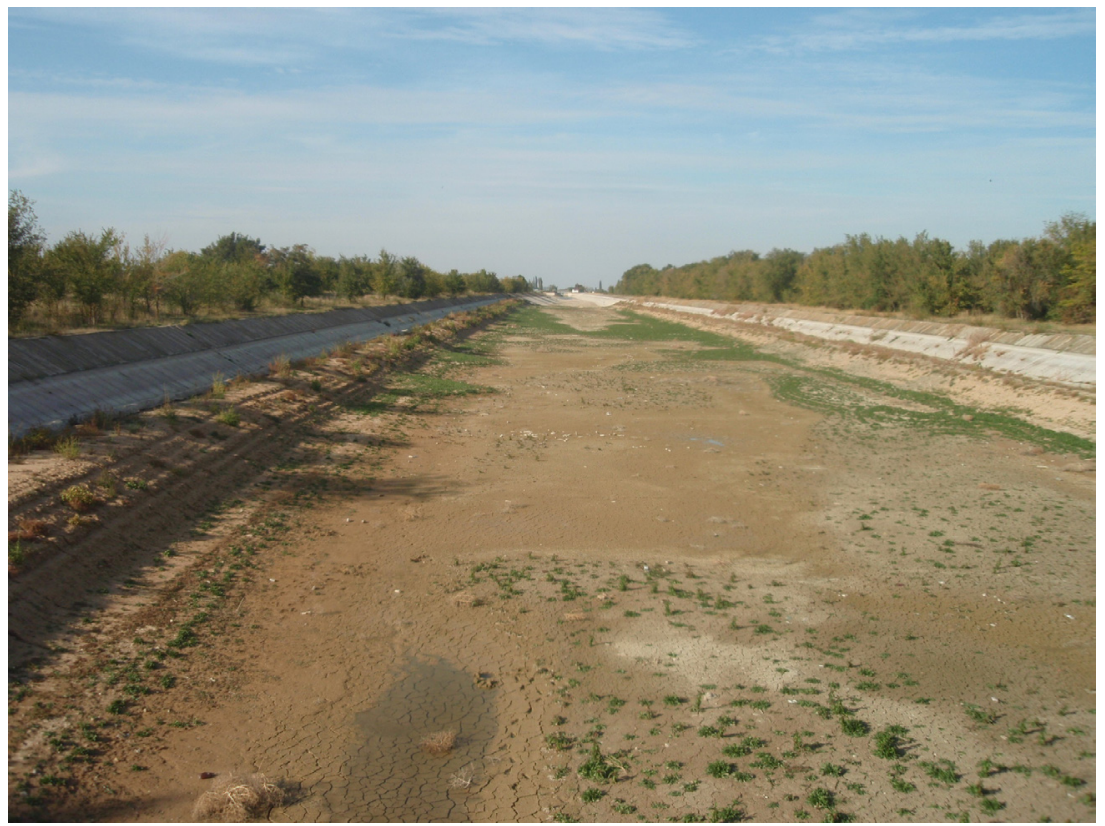

Рис. 1. Основная ветвь Северо-Крымского канала 4 октября 2014 г.

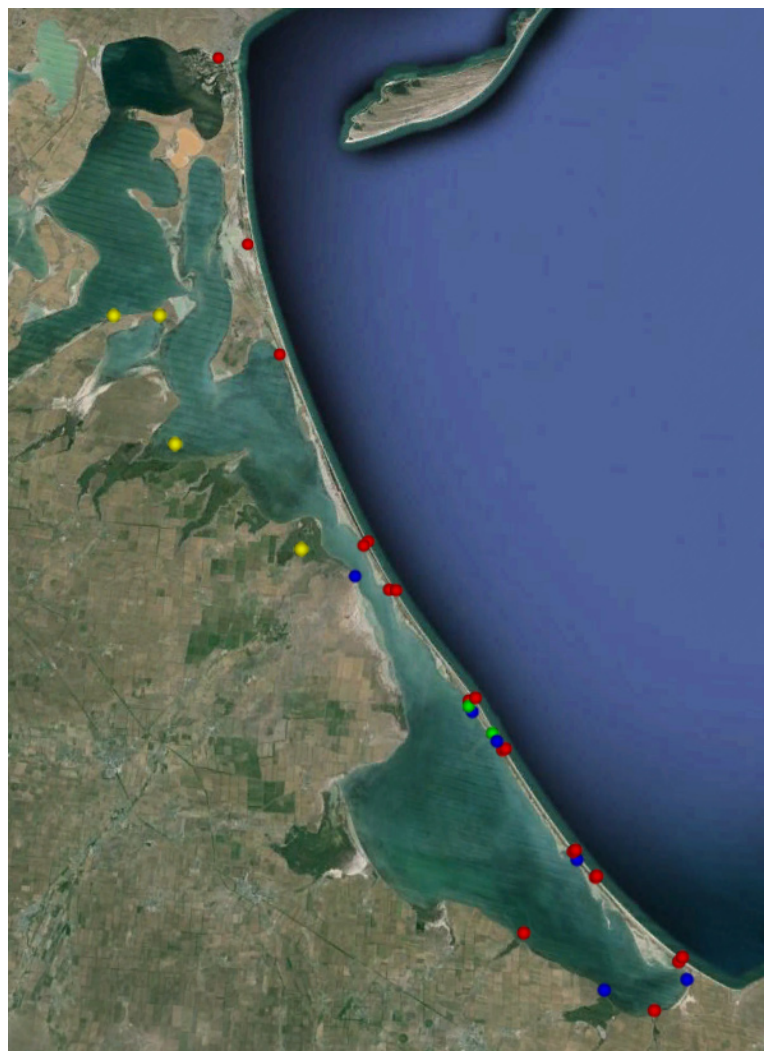

Рис. 2. Залив Сиваш: схема станций, на которых работали экспедиции (красные точки - июнь 2013 г., желтые точки - июнь и октябрь 2014 г., вторая половина октября 2015 г., синие точки - август 2015 г., зеленые точки - 2004-2015 гг., стандартные) 
0,2-0,6 м бентосными трубками (площадью $18,1 \mathrm{~cm}^{2}$, высотой 5 см) в двух повторностях. В 2014-2015 гг. количественные пробы зоопланктона отбирали путем фильтрации 100150 л воды через планктонную сеть с размером ячеи 110 мкм. Численность/плотность зоопланктона рассчитывали в экземплярах на $1 \mathrm{~m}^{3}$. Пробы фиксировали 4\%-ным формалином, обрабатывали под бинокуляром МБС-9 с использованием камеры Богорова. В августе 2015 г. укосы макрофитов (водорослевые маты) отбирали с площади 0,25 м², укосы высушивали до воздушно-сухой массы, которую пересчитывали в абсолютно сухой вес (а.с.в), используя коэффициент 0,93 (Корелякова, 1977). Массу водорослей укоса определяли на электронных весах. Относительную численность животных в матах устанавливали делением числа подсчитанных особей на массу фрагмента мата. Молодые стадии макробентических групп, имеющие линейные размеры меньше 2 мм, относили к мейобентосу. Данные подвергнуты стандартной статистической обработке в MS Excel. Для сравнения степени видового сходства таксоценов использовали индексы Жаккара и Чекановского-Серенсена (Песенко, 1982).

\section{Результаты}

20132.

Частично результаты, полученные в 2013 г., были опубликованы ранее (Сергеева и др., 2014). В 2013 г. соленость изменялась у берегов Арабатской стрелки от 10 до 40 г/л, средняя соленость была 25,2 г/л, а без учета пересохших в 2014 г. участков - 22,4 г/л. В пространственном распределении солености наблюдалась тенденция ее уменьшения в направлении с юга на север. Более высокая соленость до 40 г/л фиксировались в мелководных заливчиках и в южной части. Следует отметить, что в 2014-2015 гг. мелководные бухточки, глубина которых в 2013 г. была 10-20 см, а соленость превышала 30 г/л, оказались пересохшими. Температура воды в заливе колебалась в широких пределах - от 24,3 до $31,0{ }^{\circ} \mathrm{C}$. Температура воды была различной в местах с разной соленостью и глубиной. Средняя температура на станциях с соленостью $32-40$ г/л составляла $29,1{ }^{\circ} \mathrm{C}(\mathrm{CV}=0,038)$, а на станциях с соленостью $23-28$ г/л - 27,0 ${ }^{\circ} \mathrm{C}$ $(\mathrm{CV}=0,119)$. Средняя концентрация ОВВ в Сиваше была 3,6 мг/л $(\mathrm{CV}=0,644)$, а РОВ 2,87 мг/л (CV = 0,239).

Макробентос в 2013 г. в исследованной прибрежной полосе залива был представлен 10 таксономическими группами. Обычными были представители Amphipoda и Bivalvia (67 и $33 \%$ встречаемости соответственно). Gastropoda, Chironomidae и Tanaida отмечены на 22 \% станций, остальные таксоны, Cnidaria (Protohydra leuckarti Greeff, 1870), Oligochaeta, Isopoda, Cumacea и Bryozoa редки (11\%). Bce таксоны распределены крайне неоднородно. В одних пробах было до 5 таксонов, в других - только по одному (Bivalvia, Gastropoda, Amphipoda). Суммарная численность макрозообентоса колебалась в широких пределах от 225 до 20976 экз/м². Максимальные плотности отдельных таксонов сильно различались, максимальные значения отмечены y Amphipoda - до 18490 экз/м² и до 4970 - у Bivalvia. Достоверного влияния солености на суммарную численность макрозообентоса и распределение отдельных таксонов не выявлено.

В 2013 г. в составе мейобентоса обнаружены представители 13 крупных таксонов (Ciliophora, Foraminifera (твердораковинные и мягкораковинные), Nematoda, Turbellaria, Polychaeta, Arthropoda (Harpacticoida, Ostracoda, Amphipoda, Acari, Tardigrada, Chironomidae), Mollusca (Bivalvia, Gastropoda). По численности доминировали представи- 
тели Nematoda (в среднем 49 \% суммарного количества) и Harpacticoida (в среднем 40 \%). Количество таксонов в пробе менялось от 3 до 11, при этом никакой зависимости от солености не наблюдали. Суммарная плотность мейобентоса изменялась в широких пределах - от 5244 до 1061220 экз/м². Достоверного тренда увеличения обилия мейобентоса с ростом солености не установлено, но максимальная численность найдена при максимальной солености (36-40 г/л) на самой южной станции и в мелководном заливчике в северной части Арабатской стрелки. При этом на южной станции по количеству доминировали гарпактикоиды, а на северной нематоды. Между соленостью и отношением суммарная численность макробентоса/ суммарная численность мейобентоса выявлена достоверная негативная зависимость $(\mathrm{R}=0,64 ; \mathrm{p}=0,02)$, которая может быть аппроксимирована уравнением

$$
\mathrm{Y}=0,127-0,003 \mathrm{X}
$$

где $\mathrm{Y}$ - отношение суммарная численность макробентоса/суммарная численность мейобентоса; X - соленость, г/л.

\section{2.}

В июне 2014 г. соленость на четырех станциях в центральной части залива у западного берега (рис. 2) варьировала от 16,7 до 25,9 г/л, среднее значение - 19,54 г/л $(\mathrm{CV}=0,220)$. Температура изменялась от 25,1 до $27^{\circ} \mathrm{C}$. ОВВ в среднем составляло 10,07 мг/л $(\mathrm{CV}=0,243)$, POB - 1,11 мг/л $(\mathrm{CV}=0,092)$. В октябре на этих же станциях соленость была выше: диапазон изменений 22,7-42,2 г/л, в среднем 31,125 г/л $(\mathrm{CV}=0,247)$. Увеличились также и содержание ОВВ - среднее значение 12,04 мг/л $(\mathrm{CV}=1,068)$, и неоднородность его пространственного распределения. Температура в этот период исследований колебалась от 16,1 до $17,8^{\circ} \mathrm{C}$.

В октябре 2014 г. соленость на двух станциях у Арабатской стрелки варьировала от 50 до 65 г/л. Исходя из расположения старых выбросов морских трав выше уреза воды, оценили, что уровень воды в заливе в начале октября 2014 г. был на 20-25 см ниже, чем в предыдущие годы. Вода была необычно прозрачной, скопления нитчатых зеленых водорослей отсутствовали, свежих выбросов зостеры и рдеста у уреза воды, как в предыдущие годы, не было. Ранее в воде у берега массово встречались амфиподы, в октябре 2014 г. были найдены лишь единичные экземпляры. Общая плотность зоопланктона была высокой (1941 экз/м³), доминировали Harpacticoida (1650 экз $/ \mathrm{M}^{3}, 85 \%$ общей численности), среди которых вид Metis ignea ignea Philippi, 1843 составлял 6-7 \%. В планктоне также единично присутствовали Calanoida, Cyclopoida, Ostracoda, личинки Chironomidae и Bivalvia, яйца Artemia.

20152.

В августе 2015 г. была проведена экспедиция на Арабатскую стрелку и западный берег залива (рис. 2). В летне-осенний период 2004-2013 гг. соленость воды на станциях в центральной части колебалась от 17 до 19 г/л, а в августе 2015 г. составляла 55-65 и 70-75 г/л в южной части залива. Температура воды (среднее значение $30,3{ }^{\circ} \mathrm{C}, \mathrm{CV}=0,029$ ) по сравнению с предыдущими годами в августе выросла на $1,5-2{ }^{\circ} \mathrm{C}$. Визуально отмечено увеличение площади пересохших участков, уменьшение количества и размеров придаточных водоемов на Арабатской стрелке. Используя положение полосы старых выбросов морских трав (рис. 3), оценили падение уровня воды с 2013 г., уровень уменьшился на 25$30 \mathrm{~cm}$. 


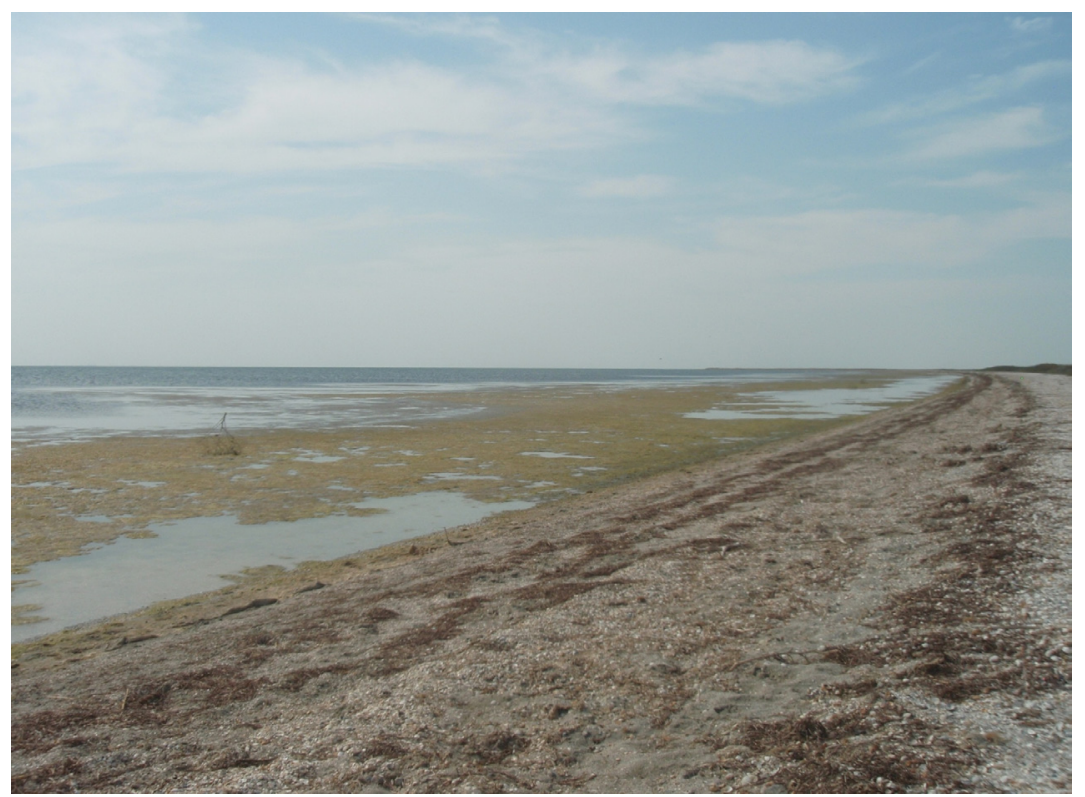

Рис. 3. Плавучие маты зеленой нитчатой водоросли Cladophora siwaschensis у берегов Арабатской стрелки и остатки старых выбросов морских трав у бывших урезов воды

В 2015 г. в макрозообентосе мягких грунтов было отмечено 9 таксонов: Cnidaria (частота встречаемости $25 \%$ ), Turbellaria (25\%), Nemertini (25\%), Polychaeta (50\%), Bivalvia (75\%), Gastropoda (100\%), Crustacea (Amphipoda (50\%), Isopoda (25\%)), Insecta личинки Chironomidae (75 \%). В пробах встречалось от 3 до 6 таксонов. Общая численность организмов макробентоса менялась от 5473 до 194081 экз/м². Средняя плотность макрозообентоса в 2015 г. была почти в 10 раз больше таковой в 2013 г. На половине станций доминировали Gastropoda, 59-69 \% от общего количества. На остальных станциях преобладали Chironomidae (до $42 \%$ общего обилия) или Polychaeta (до 47 \%). Доминировавшие по численности в 2013 г. Amphipoda и Bivalvia в 2015 г. имели очень низкие показатели. Ранее в воде у берега массово встречались амфиподы, в октябре 2014 г. были найдены лишь единичные экземпляры. При этом количество Bivalvia даже увеличилось, но присутствовала в основном одна молодь. На протяжении
2014 и 2015 гг. на берегу сформировались валы из выброшенных раковин недавно погибших взрослых двустворчатых моллюсков, в основном Cerastoderma glaucum (Bruguiere, 1789), наиболее мощные на западном берегу залива (рис. 4).

Мейобентос был представлен 11 мегатаксонами: Ciliophora, Foraminifera (твердораковинные и мягкораковинные), Nematoda, Turbellaria, Nemertini, Polychaeta, Arthropoda (Harpacticoida, Ostracoda, Acari, Chironomidae), Gastropoda. В пробе присутствовали представители 7-10 таксонов. Суммарная численность мейобентоса на большинстве стаций была высокой - от 960720 до 3000890 экз $/ \mathrm{M}^{2}$, по сравнению с 2013 г. она увеличилась в среднем в 3 раза. На большинстве станций доминировали Nematoda, давая от 38 до $50 \%$ общей численности, а Harpacticoida - 8-31\%. В большинстве проб Mesochra cf. rostrata Gurney, 1927 был наиболее массовым видом - 80-100 \% от численности всех гарпактикоид. Зарегистрирована 


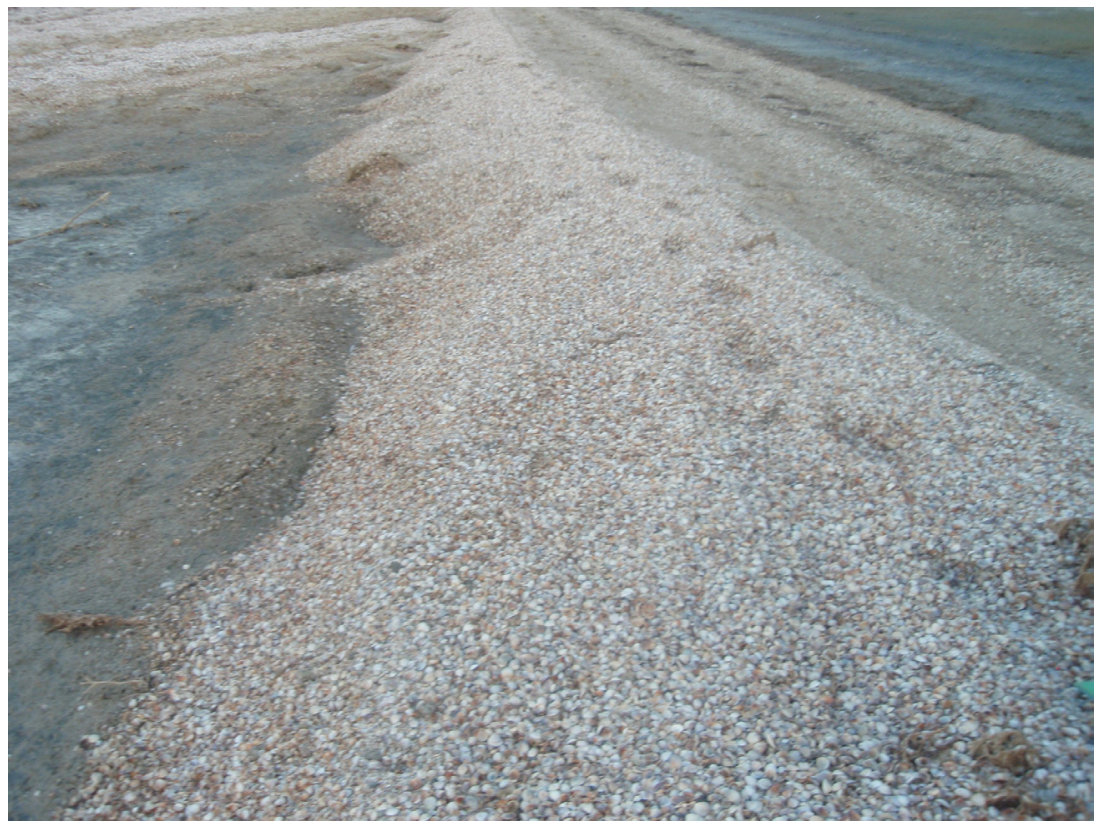

Рис. 4. Валы недавно выброшенных раковин двустворчатых моллюсков на западном берегу залива Сиваш, август 2015 г.

хорошо развитая популяция этого вида, значительная доля самцов, самок с яйцевыми мешками, найдены науплиальные и копеподитные стадии развития. В одной пробе высокую численность демонстрировал вид Microarthridion littorale (Poppe, 1881) (56 \% общей численности таксона). На одной станции у западного берега залива отмечена наименьшая численность макро- $(5473$ экз/м²) и мейобентоса (3789 экз/м²), и доминировали в мейобентосе Ciliophora, 85 \% общей численности. Отношение численность макробентоса/численность мейобентоса в этой точке составляло 1,44. В других точках оно было меньше и изменялось в 12 раз, в диапазоне 0,007-0,085. В 2013 г. это отношение изменялось лишь в 6,5 раза $(0,002-0,013)$.

Отмечено присутствие зеленой водоросли кладофоры Cladophora siwaschensis C. Meyer как в 2013 г., так и в 2015 г. Однако если ранее кладофора регистрировалась в незначительном количестве, то в 2015 г. вдоль берегов
Арабатской стрелки она формировала широкие (до 30-50 м и более) полосы плавучих матов (рис. 3) (с биомассой 140-415 г/м² (а.с.в.). Маты стали ключевым элементом экосистемы Сиваша. Средняя численность животных на 1 г сухой массы мата составляла 1476 экз. $(\mathrm{CV}=0,080)$, или 210-613 тыс. экз $/ \mathrm{M}^{2}$. Основу численности животных в матах составляли Harpacticoida (от 73 до 86 \% общей численности). В матах присутствовали Ostracoda, Bivalvia, Gastropoda, Amphipoda, Chironomidae и Polychaeta (Hediste diversicolor (Muller, 1776) и Genetyllis tuberculata (Bobretzky, 1868)), а также молодь бычка Knipowitschia caucasica (Berg, 1916). Среди матов при солености до 65 г/л были многочисленны быстро плавающие стайки молоди атерины Atherina pontica (Eichwald, 1931). Следует отметить, что под плавучими матами часто формируются гипоксийные и даже аноксийные условия, о чем свидетельствует черный цвет донных осадков и их запах. 
В зоопланктоне наблюдали Наrpacticoida, Calanoida, Cyclopoida, Ostracoda, Amphipoda и в небольшом количестве яйца Artemia. Доминировали Нarpacticoida (до 97 \% общего количества) или Ostracoda (до $64 \%$ ). Среди Harpacticoida вид M. ignea ignea составлял 26-92\% (66 \% в среднем). У Арабатской стрелки зоопланктон распределялся неравномерно, его плотность колебалась от 300 до 9000 экз $/ \mathrm{M}^{3}$. У западных берегов его плотность (от 20 до 1740 экз $/ \mathrm{M}^{3}$ ) и разнообразие (практически только Harpacticoida и Ostracoda) были ниже.

Еще одна экспедиция в октябре 2015 г. работала на тех же станциях западного берега залива, что в июне и октябре 2014 г. Температура воды на станции с соленостью 28 г/л была $11{ }^{\circ} \mathrm{C}$, а на станциях с соленостью 38,6 49,6 г/л - 12,5-13,5 ${ }^{\circ} \mathrm{C}$. Средняя соленость составляла 40 г/л, диапазон - 28,0-49,6 г/л $(\mathrm{CV}=0,230)$. Исходя из приведенных выше данных прослеживается четкий тренд увеличения средней солености в заливе с июня 2014 г. по октябрь 2015 г. на этих станциях (рис. 5). Содержание ОВВ составляло в среднем 10,5 мг/л $(\mathrm{CV}=0,700)$. На рис. 6 видно, что концентрация ОВВ в заливе в период с июня 2013 г. по октябрь 2014 г. выросла более чем в три раза (рис. 6). Различия концентрации в 2013 г. и 2014-2015 гг. достоверны $(\mathrm{p}=0,0001)$. Средняя концентрация РОВ составляла 1,99 мг/л $(\mathrm{CV}=0,231)$. В 2014-2015 гг. концентрация РОВ была ниже, чем в 2013 г. С июня 2013 г. по июнь 2014 г. произошло достоверное $(\mathrm{p}=0,001)$ уменьшение концентрации POB, а затем к октябрю 2015 г. она увеличилась $(\mathrm{p}=0,05)$. Концентрации РОВ в 2013 г. и 2015 г. достоверно не различались.

\section{Обсуждение}

Все приведенные выше данные свидетельствуют о том, что рост солености запу-

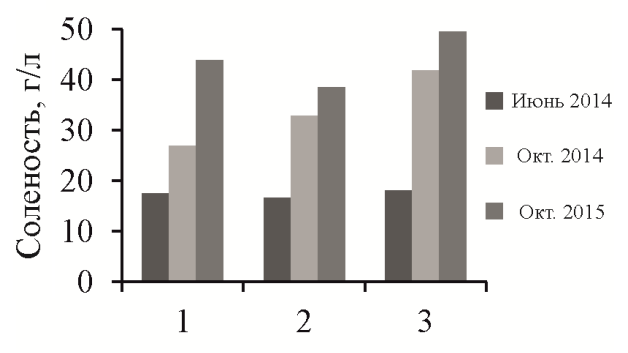

Рис. 5. Изменение солености на трех станциях у западного берега залива Сиваш в 2014-2015 гг.

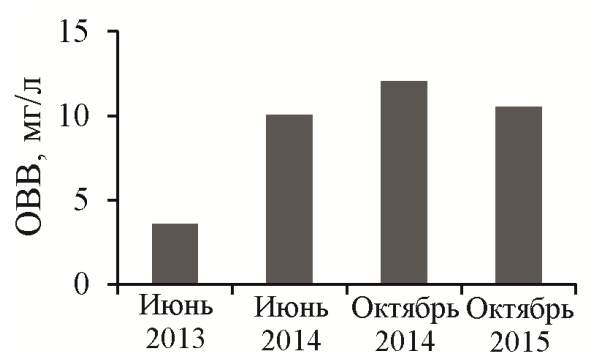

Рис. 6. Изменение средней концентрации общего взвешенного вещества (OBB) в заливе Сиваш в 20132015 гг. 
стил процесс кардинальной трансформации всей экосистемы Сиваша, включая бентос. Известно, что с ростом солености теплоемкость воды убывает и, как следствие, вода быстрее и сильнее нагревается в летние дни. Как показали наши данные, соленость влияет на температуру воды в заливе. Влияние солености на температуру воды наблюдали в Мертвом море и в гипергалинных водоемах Крыма и Индии (Steinhorn, 1997; Шадрин, 2012a). Некоторое увеличение температуры в Сиваше в большей степени обусловлено ростом солености, чем глобальным потеплением. С увеличением солености растворимость кислорода в воде уменьшается, как и при росте температуры (Шадрин, 2012a). Это повышает вероятность возникновения аноксийных и гипоксийных явлений и $30 н$ в заливе, что может вести к уменьшению разнообразия и среднего размера животных (Gibson, Atkinson, 2003; Levin et al., 2009).

Значительное увеличение ОВВ в заливе (рис. 6) нельзя объяснить увеличением поступления взвешенного вещества с водосбора, так как произошло существенное уменьшение, почти до нуля, сброса дренажных вод в Сиваш. Вероятнее всего, резкий рост солености привел к массовой гибели разных видов, например двустворчатых моллюсков (рис. 4). Разрушение этой мертвой органики и могло вызвать трехкратное увеличение концентрации ОВВ. Распространение плавучих матов ведет к трансформации придонной среды из окислительной в восстановительную, подобное ранее отмечалось в других гипергалинных замкнутых лагунах Крыма (Shadrin, Anufriieva, 2013).

Изменилась таксономическая структура сообщества. Разнообразие крупных таксонов в макро- и мейобентосе несколько уменьшилось, некоторые из них полностью «выпали» из экосистемы: в макробентосе -
Oligochaeta, Cumaceа и Tanaida, а в мейобентосе - молодь Amphipoda, Acari, Tardigrada. В планктоне практически исчезли мизиды и амфиподы, которые ранее были массовыми (Загородняя, 2006). В то же время в зообентос добавились Nemertini. Если в макробентосе ранее доминировали крупнотелые виды Bivalvia и Amphipoda, то в 2015 г. доминирование перешло к Chironomidae, Polychaeta и мелкоразмерным Gastropoda. Уменьшение средних размеров в макробентосе можно объяснить периодическими заморами, которые возникают в придонном слое из-за дефицита кислорода. Летом падение концентрации кислорода до нуля ночью у дна может происходить ежесуточно, что обнаружено при подобных условиях в лагуне-озере Бакальском (Шадрин, 2008). Мелкоразмерные животные более успешно переносят гипоксийные и аноксийные условия (Gibson, Atkinson, 2003; Levin et al., 2009). Можно предположить, что увеличение численности мелкоразмерного зообентоса на рыхлых грунтах, прежде всего, обусловлено увеличением ОВВ и поступлением на дно органического вещества, синтезированного кладофоровыми матами. В 2014-2015 гг. визуально наблюдали намного меньше кормящихся на акватории птиц, чем в предыдущие годы, что также могло способствовать увеличению численности зообентоса. Ранее в зоопланктоне Сиваша доминировали личинки донных животных Cirripedia, Bivalvia, Polychaeta (Загородняя, 2006), которые в 2014-2015 гг. были представлены лишь единичными экземплярами. Донные животные почти перестали размножаться в заливе. Можно предположить, что при дальнейшем росте солености произойдет существенное уменьшение количества мегатаксонов бентосных животных, существующих в Сиваше. Если тенденция роста 
солености сохранится, то в 2017-2018 гг. макрозообентоса, за исключением хирономид, в заливе может не остаться - такой прогноз следует из результатов исследования крымских гиперсоленых водоемов (Балушкина и др., 2009; Belmonte et al., 2012).

В 2015 г. по сравнению с 2013 г. изменилась и видовая структура массовых таксонов мейобентоса, в частности Harpacticoida. Сравнение списка видов Harpacticoida дано в табл. 1. Суммарное число видов несколько возросло: 8 видов в 2015 г. и 7 - в 2013 г. Количество видов на мягких грунтах уменьшилось с 7 до 4. Сходство видовой структуры анализировали в двух вариантах: только для таксоцена мягких грунтов и суммарно для всех сравниваемых биотопов. В первом случае коэффициент Жаккара был равен 0,22, коэффициент Чекановского-Серенсена - 0,37. Во втором случае коэффициент Жаккара был равен 0,25, коэффициент ЧекановскогоСеренсена - 0,40. Пороговые значения для вывода о сходстве видовой структуры со- общества/таксоцена составляют 0,42 (коэффициент Жаккара) и 0,59 (коэффициент Чекановского-Серенсена) (Сёмкин, 2009), из чего можно сделать вывод, что структура таксоцена Harpacticoida существенно изменилась. Некоторое увеличение числа видов можно объяснить тем, что сообщество находится в состоянии хаотизации и реорганизации в новое состояние (Holling, 2001; Шадрин, 2012б). Следует отметить и то, что большинство видов Harpacticoida было обнаружено в 2015 г. только в планктоне. Массовое присутствие бентосных животных в планктоне в условиях высокой солености наблюдали и ранее (Загородняя и др., 2008). Высокая галотолерантность большинства отмеченных видов известна (Anufriieva, 2015). Например, Cletocamptus retrogressus Schmankevitsch, 1875 встречается в Крыму при солености выше 300 г/л, Metis ignea ignea Philippi, 1843 - при солености выше 250 г/л и Nitokra spinipes spinipes Boeck, 1865 - при солености до 240 г/л.

Таблица 1. Видовой состав Нarpacticoida в биотопах залива Сиваш в разные годы

\begin{tabular}{|c|c|c|c|c|c|c|}
\hline \multirow{2}{*}{ Вид } & \multicolumn{3}{|c|}{2013} & \multicolumn{3}{|c|}{2015} \\
\hline & 1 & 2 & 3 & 1 & 2 & 3 \\
\hline Ameira parvula (Claus, 1866) & + & нд & нд & - & - & - \\
\hline Canuella perplexa T. et A. Scott, 1893 & + & нд & нд & + & - & + \\
\hline Cletocamptus retrogressus Schmankevitsch, 1875 & - & нд & нд & - & - & + \\
\hline Harpacticus littoralis G. O. Sars, 1910 & - & нд & нд & - & - & + \\
\hline Harpacticus flexus Brady et D. Robertson, 1873 & + & нд & нд & - & - & - \\
\hline Mesochra heldti Monard, 1935 & + & нд & нд & - & - & - \\
\hline *Mesochra cf. rostrata Gurney, 1927 & + & нд & нд & + & + & + \\
\hline Mesochra sp. & + & нд & нд & - & - & - \\
\hline Metis ignea ignea Philippi, 1843 & - & нд & нд & + & + & + \\
\hline Microarthridion littorale (Poppe, 1881) & - & нд & нд & + & - & + \\
\hline Nitokra spinipes spinipes Boeck, 1865 & + & нд & нд & - & - & + \\
\hline Copepoda parasitica & - & нд & нд & - & - & + \\
\hline
\end{tabular}

Примечание: 1 - мягкие грунты, 2 - плавучие маты нитчатых зеленых водорослей, 3 - планктон, + вид присутствовал, вид отсутствовал, нд - нет данных, * вид впервые найден в Черноморском бассейне (Сергеева и др., 2014). 


\section{Заключение}

Рост солености в заливе Сиваш привел к реорганизации структуры не только бентоса, но и всей экосистемы. Ранее в гиперсоленых водоемах Крыма при солености 60-75 г/л не наблюдали столь высокого разнообразия видов и таксономических групп животных (Балушкина и др., 2009; Belmonte et al., 2012; Shadrin, Anufriieva, 2013). Bepoятно, это явление гистерезиса (Шадрин, 2013): при одной и той же солености может наблюдаться разное биоразнообразие, если соленость растет, то оно будет выше, чем если она падает. Закончится ли современная трансформация экосистемы залива возвратом к состоянию, в котором она была в первой половине XX в.? Это могут показать лишь дальнейшие исследования, которые приблизят нас к пониманию общих закономерностей трансформации водных экосистем.

\section{Благодарности}

Работа выполнена при частичной поддержке Otto Kinne Foundation (E.B. Ануфриевой), Российского фонда фундаментальных исследований - гранты № 13-04-02055-а (Л.М. Киприяновой) и № 16-05-00134 (Е.В. Ануфриевой и Н.В. Шадрину).

Авторы благодарны А.И. и Д.А. Киприяновым, помогавшим при проведении полевых работ, Р.Е. Романову, В.Е. Гирагосову, Е.П. Карповой и Е.В. Лисицкой за консультации и помощь в определении видов, а также анонимным рецензентам, советы которых содействовали улучшению рукописи.

\section{Список литературы}

Аладин Н.В., Плотников И.С. (2008) Современная фауна остаточных водоемов, образовавшихся на месте бывшего Аральского моря. Труды Зоологического института РАН, 312 (1-2): 145-154 [Aladin N.V., Plotnikov I.S. (2008) Modern fauna of residual water bodies formed on the place of the former Aral Sea. Proceedings ZIN RAS [Trudy Zoologicheskogo instituta RAN], 312 (1-2): 145-154 (in Russian)]

Балушкина Е.В., Голубков, С.М., Голубков М.С., Литвинчук Л.Ф., Шадрин Н.В. (2009) Влияние абиотических и биотических факторов на структурно-функциональную организацию экосистем соленых озер Крыма. Журнал общей биологии, 70 (6): 504-514 [Balushkina E.V., Golubkov S.M., Golubkov M.S., Litvinchuk L.F., Shadrin N.V. (2009) Effect of abiotic and biotic factors on the structural and functional organization of the saline lake ecosystems. Biology Bulletin Reviews [Zhurnal obshchei biologii], 70 (6): 504-514 (in Russian)]

Воробьев В.П. (1940) Гидробиологический очерк Восточного Сиваша и возможности его рыбохозяйственного использования. Труды АзЧерНИРО, 12: 69-164 [Vorobyev V.P. (1940) Hydrobiological essay on the Eastern Sivash and its potential for fisheries. Proceedings of AzCherNIRO [Trudy AzCHerNIRO], 12: 69-164 (in Russian)]

Гетманенко В.А., Яновский Е.Г., Гроте Г.Г. (1996) Влияние полумеханических драг на зообентос Восточного Сиваша (Азовское море). Гидробиологический журнал, 32 (1): 54-60 [Getmanenko V.A., Yanovsky Ye.G., Grout G.G. (1996) Impact of semi-mechanical trawling on the zoobenthos of the Eastern Sivash (Azov Sea). Hydrobiological Journal [Gidrobiologicheskii Zhurnal], 32 (1): 54-60 (in Russian)]

Гринченко А.Б. (2004) История и динамика колониальных поселений аистообразных птиц в восточных районах Крыма в связи с антропогенной сукцессией Восточного Сиваша

$$
-463-
$$


и Присивашья. Бранта: Сборник научных трудов Азово-Черноморской орнитологической станции, 7: 61-81 [Grinchenko A.B. (2004) History and dynamics of colonial settlements of Ciconiidae in the Eastern Crimea under the influence of anthropogenic succession at the Eastern Sivash and near Sivash area. Branta: Transactions of the Azov-Black Sea Ornithological Station [Branta: Cbornik nauchnyh trudov Azovo-Chernomorskoj ornitologicheskoj stancii], 7: 61-81 (in Russian)]

Загородняя Ю.А. (2006) Таксономический состав и количественные характеристики зоопланктона в Восточном Сиваше летом 2004 г. Экосистемные исследования Азовского, Черного и Каспийского морей, 8: 103-114 [Zagorodnyaya Yu.A. (2006) The taxonomic composition and quantitative characteristics of zooplankton in the eastern part of Gulf Sivash during summer 2004. Ecosystem researches of the Azov Sea, the Black Sea and the Caspian Sea [Ekosistemnye issledovaniya Azovskogo, Chernogo i Kaspijskogo morej], 8: 103-114 (in Russian)]

Загородняя Ю.А., Батогова Е.А., Шадрин Н.В. (2008) Многолетние трансформации планктона в гипергалинном Бакальском озере (Крым) при колебаниях солености. Морской экологический журнал, 7 (4): 41-50 [Zagorodnyaya Yu.A., Batogova E.A., Shadrin N.V. (2008) Long-term transformation of zooplankton in the hypersaline lake Bakalskoe (Crimea) under salinity fluctuations. Marine Ecological Journal [Morskoi ecologicheskii zhurnal], 7 (4): 41-50 (in Russian)]

Зенкевич Л.А. (1963) Биология морей СССР. М., Изд-во АН СССР, 740 с. [Zenkevitch L.A. (1963) Biology of the Seas of the U.S.S.R. Moscow, Nauka, 740 p. (in Russian)]

Киреева И.Ю., Потеха В.П. (2013) Оценка лова промыслово-ценных гидробионтов в заливе Сиваш. Вестник АГТУ, Серия Рьбное хозяйство, 2: 58-66 [Kireeva I.Yu., Potekha V.P. (2013) Assessment of fishing the valuable hydrobionts in the Sivash bay. Vestnik of Astrakhan State Technical University. Series: fishing industry [Vestnik AGTU, Seriya Rybnoe hozyajstvo], 2: 58-66 (in Russian)]

Корелякова И.Л. (1977) Растительность Кременчугского водохранилища. Киев, Наукова думка, 198 с. [Korelyakova I.L. (1977) Vegetation of the Kremenchug reservoir. Kiev, Naukova Dumka, 200 p. (in Russian)]

Мокиевский В.О. (2009) Экология морского мейобентоса. М., Товарищество научных изданий КМК, 235 c. [Mokievsky V.O. (2009) Ecology of marine meiobenthos. Moscow, KMK Scientisic Press, 286 p. (in Russian)]

Песенко Ю.А. (1982) Принципы и методы количественного анализа в фаунистических исследованиях. М., Наука, 287 c. [Pesenko Yu.U. (1982) Principles and methods of quantitative analysis in faunal studies. Moscow, Nauka, 287 p. (in Russian)]

Сергеева Н.Г., Колесникова Е.А., Латушкин А.А., Чепыженко А.А. (2014) Разнообразие мейобентоса рыхлых грунтов озера Сиваш. Биоразнообразие и устойчивое развитие: Материалье 3-й Междунар. научно-практ. конф. Симферополь, с. 323-325 [Sergeeva N.G., Kolesnikova E.A., Latushkin A.A., Chepyzhenko A.A. (2014) A variety of loose soils meiobenthos Sivash Lake. Biodiversity and Sustainable Development: Proceedings the 3rd Intern. Scient. Conf. Simferopol, p. 323-325 (in Russian)]

Сёмкин Б.И. (2009) О связи между средними значениями двух мер включения и мерами сходства. Бюллетень Ботанического сада-института ДВО РАН, 3: 91-101 [Semkin B.I. (2009) On the relation between mean values of two measures of inclusion and measures of similarity. Bulletin 
of Botanical Garden-Institute FEB RAS [Biulleten' Botanicheskogo sada-instituta DVO RAN], 3: 91101 (in Russian)]

Шадрин Н.В. (2008) Гиперсоленые озера Крыма: общие особенности. Микроводоросли Черного моря: проблемь сохранения биоразнообразия и биотехнологического использования. Токарев Ю.Н., Финенко 3.3., Шадрин Н.В. (ред.) Севастополь, ЭКОСИ-Гидрофизика, с. 85-93 [Shadrin N.V. (2008) The Crimean hypersaline lakes: general peculiarities. The Black Sea microalgae: problems of biodiversity preservation and biotechnological usage. Tokarev Yu.N., Finenko Z.Z., Shadrin N.V. (eds.) Sevastopol, ECOSI- Gidrofizika, p. 85-118 (in Russian)]

Шадрин Н.В. (2012а) Ракообразные в гиперсоленых водоемах: специфика существования и адаптация. Актуальные проблемы изучения ракообразных континентальных вод: Материаль лекиий и докладов Международ. школь-конф. Борок, с. 316-319 [Shadrin N.V. (2012a) Crustaceans in hypersaline water bodies: the specificity of the existence and adaptation. Contemporary problems of crustacean study in the continental waters. Proceedings of International school-conference. Borok, p. 316-319 (in Russian)]

Шадрин Н.В. (2012б) Динамика экосистем и эволюция: множественность устойчивых состояний и точки опрокидывания/невозврата. Необходимость нового понимания. Морской экологический журнал, 11 (2): 85-95 [Shadrin N.V. (2012b) Ecosystem dynamics and evolution: multiplicity of steady states and tipping points. Necessity of new understanding. Marine Ecological Journal [Morskoi ecologicheskii zhurnal], 11 (2): 85-95 (in Russian)]

Шадрин Н.В. (2013) Альтернативные устойчивые состояния озерных экосистем: есть ли жесткая связь? Труды Зоологического института РАН, 3: 214-221 [Shadrin N.V. (2013) Alternative stable states of lake ecosystems and critical salinities: Is there a rigid connection? Proceedings ZIN $R A S$ [Trudy Zoologicheskogo instituta RAN], 3: 214-221 (in Russian)]

Anufriieva E.V. (2015) Do copepods inhabit hypersaline waters worldwide? A short review and discussion. Chinese Journal of Oceanology and Limnology, 33 (6): 1354-1361

Belmonte G., Moscatello S., Batogova E.A., Pavlovskaya T., Shadrin N.V., Litvinchuk L.F. (2012) Fauna of hypersaline lakes of the Crimea (Ukraine). Thalassia Salentina, 34: 11-24

Conley D.J., Carstensen J., Ærtebjerg G., Christensen P.B., Dalsgaard T., Hansen J.L., Josefson A.B. (2007) Long-term changes and impacts of hypoxia in Danish coastal waters. Ecological Applications, 17 (sp5): S165-S184

El-Shabrawy G.M., Anufriieva E.V., Germoush M.O., Goher M.E., Shadrin N.V. (2015) Does salinity change determine zooplankton variability in the saline Qarun Lake (Egypt)? Chinese Journal of Oceanology and Limnology, 33 (6): 1368-1377

Ezhova E., Żmudziński L., Maciejewska K. (2005) Long-term trends in the macrozoobenthos of the Vistula Lagoon, southeastern Baltic Sea. Species composition and biomass distribution. Bulletin of the Sea Fisheries Institute, 1 (164): 55-73

Gibson R.N., Atkinson R.J.A. (2003) Oxygen minimum zone benthos: adaptation and community response to hypoxia. Oceanography and Marine Biology: An Annual Review, 41: 1-45

Holling C.S. (2001) Understanding the complexity of economic, ecological, and social system. Ecosystems, 4: 390-405

Levin L.A., Ekau W., Gooday A.J., Jorissen F., Middelburg J.J., Naqvi S.W.A., Zhang J. (2009) Effects of natural and human-induced hypoxia on coastal benthos. Biogeosciences, 6 (10): 2063-2098.

$$
-465-
$$


Semprucci F., Frontalini F., Sbrocca C., du Châtelet E.A., Bout-Roumazeilles V., Coccioni R., Balsamo M. (2015) Meiobenthos and free-living nematodes as tools for biomonitoring environments affected by riverine impact. Environmental Monitoring and Assessment, 187 (5): 1-19

Sergeeva N.G., Zaika V.E. (2013) The Black Sea meiobenthos in permanently hypoxic habitat. Acta Zoologica Bulgarica, 65 (2): 139-150

Shadrin N.V., Anufriieva E.V. (2013) Climate change impact on the marine lakes and their Crustaceans: The case of marine hypersaline Lake Bakalskoye (Ukraine). Turkish Journal of Fisheries and Aquatic Sciences, 13: 603-611

Steinhorn I. (1997) Evaporation estimate for the Dead Sea: essential considerations for saline lakes. The Dead Sea: The Lake and Its Setting. Niemi T.M., Ben-Avraham Z., Gat J.R. (eds.) Oxford, Oxford University Press, p. 122-132

Zeppilli D., Sarrazin J., Leduc D., Arbizu P.M., Fontaneto D., Fontanier C., Gooday A.J., Kristensen R.M., Ivanenko V.N., Vanreusel A. (2015) Is the meiofauna a good indicator for climate change and anthropogenic impacts? Marine Biodiversity, 45 (3): 505-535 